\title{
Characteristics and Sources of Organic Aerosol Markers in $\mathrm{PM}_{2.5}$
}

Aerosol and Air Quality Research

\section{OPEN ACCESS}

Received: July 24, 2021

Revised: August 7, 2021

Accepted: August 18, 2021

${ }^{*}$ Corresponding Authors: Jingjing Meng

mengjingjing@Icu.edu.cn

Li Yan

yanli@caep.org.cn

\section{Publisher:}

Taiwan Association for Aerosol Research

ISSN: $1680-8584$ print ISSN: 2071-1409 online

Copyright: The Author(s). This is an open access article distributed under the terms of the Creative Commons Attribution License (CC BY 4.0), which permits unrestricted use, distribution, and reproduction in any medium, provided the original author and source are cited.

\author{
Zheng Li ${ }^{1}$, Ruiwen Zhou ${ }^{1}$, Yuanyuan Li ${ }^{1}$, Min Chen ${ }^{1}$, Yachen Wang ${ }^{1}$, \\ Tonglin Huang ${ }^{1}$, Yanan $\mathrm{Yi}^{1}$, Zhanfang Hou ${ }^{1}$, Jingjing Meng ${ }^{1 *}$, Li Yan ${ }^{2 *}$ \\ ${ }^{1}$ School of Geography and the Environment, Liaocheng University, Liaocheng 252000, China \\ ${ }^{2}$ Chinese Academy for Environmental Planning, Beijing 100012, China
}

Keywords: Organic aerosols, Levoglucosan, Biomass burning, PAHs, Jinan city

\section{INTRODUCTION}

Haze, a weather phenomenon that causes the atmosphere visibility $<10 \mathrm{~km}$ because of the mixed state of vapor, smoke, and suspended particles in the atmosphere (Lee et al., 2014). The air pollution and severe haze events are usually observed during wintertime in Northern China due to the enhanced anthropological emissions and poor meteorological conditions (Fu et al. 2008; Kong et al., 2015; Wang et al., 2017). For example, one month-long haze event in the begin of 2013 covered an area of more than $1.3 \times 10^{6} \mathrm{~km}^{2}$ and affected more than 800 million populations (An et al., 2019). Improved comprehending the physical or chemical processing which can result in the formation of haze is very essential to devise effective prevention measures (Zhang et al., 2020). Previous researches have illustrated that organic components play a significant role in the haze occurrence in the NCP, especially the secondary aerosols (SOA) (Huang et al., 2014; Zhou et al., 2017).

OAs typically account for as much as $75 \%$ of $\mathrm{PM}_{2.5}$ mass in urban atmosphere and attract much public attention because of their important influence on human health, visibility, and climate change (Huang et al., 2014; An et al., 2019; Li et al., 2019a; Ari et al., 2020; Meng et al., 2020). In addition, OAs can change the aerosols hygroscopic properties, because most of OAs (up to $80 \%$ ) 
are water-soluble and play important roles in radiative forcing via affecting cloud condensation nuclei (CCN) (Meng et al., 2018; Yi et al., 2021). OAs are derived from multiple sources and their formation involves several atmospheric processes. For example, primary organic aerosol (POA) can be delivered directly from vehicle emissions, combustion sources, and plant emissions, whereas SOA are principally formed from the oxidation of volatile organic compounds (VOCs) (Hallquist et al., 2009; Zhou et al., 2017). Sugars are the relatively abundant water-soluble organic components in atmosphere, which can enter atmosphere through biomass burning, soil resuspension, and plant emissions (Wan and Yu, 2007; Li et al., 2017a). Fatty acids, abundantly existing in OAs in the urban atmosphere (Oliveira et al., 2007), which contribute to more than $50 \%$ of detected organic components from different emission sources (e.g., biological activities, biomass burning, and cooking activities) (Ho et al., 2011; Liu et al., 2019). Both PAHs and OPAHs are mostly derived from the incomplete combustion of solid fuels including fossil fuels and biomass (Wang et al., 2016). Besides the direct sources, PAHs can be oxidized by atmospheric oxidants to form OPAHs (Wei et al., 2012; Niu et al., 2017). Recently, PAHs and OPAHs have been listed as persistent pollutants because of their high carcinogenicity and mutagenicity (Shi et al., 2014; Kong et al., 2015; Li et al., 2019b). OPAHs are regarded as pivotal category in the reactive oxygen species (ROS) formation, which in turn can induce oxidative trauma in biological molecules (Lin et al., 2015; Wang et al., 2016; Niu et al., 2017). High PAHs and OPAHs concentrations were widely observed in haze period during the wintertime because of the incremental consumption of fossil fuels and/or stagnant meteorology (Tan et al., 2011; He et al., 2014; Liu et al., 2019). In sum, the molecular characteristics, concentration levels, and sources of OAs were different in diverse regions due to the complex energy structure and atmospheric environment. Therefore, it is becoming more significant to carry out a deep research on the sources and evolution processes of OAs.

China, the largest developing country all over the world, has been experiencing severe air pollution in the past few years (An et al., 2019; Li et al., 2020; Meng et al., 2020). PM2.5 pollution is the dominant environment issue in the NCP, which has been considered as one of the most polluted area in the world (Yang et al., 2018; Li et al., 2019a). As a typical industrial city, Jinan is the representative of the urban cities in the NCP. Though the overall air quality was improved in Jinan, for example, $\mathrm{PM}_{2.5}$ concentration decreased markedly from $204.9 \mu \mathrm{g} \mathrm{m}^{-3}$ in 2012 to 114.4 $\pm 56.9 \mu \mathrm{g} \mathrm{m}^{-3}$ in 2016 (Yang et al., 2012), haze events still occurred frequently. However, previous studies in Jinan were mainly focused on the sources and characteristics of carbonaceous species and water-soluble ions (Gao et al., 2011; Zhou et al., 2017), while the pollution characteristics and potential source regions of OAs during the wintertime have not been fully elucidated, especially during haze events. Hence, this study will deepen our comprehending of the characteristics and source areas of $\mathrm{PM}_{2.5}$ in haze periods, which can further provide scientific guidance for the pollution prevention in the local and surrounding region.

\section{MATERIALS AND METHODS}

\subsection{Aerosol Sampling}

Jinan is located in the center of Shandong Province, between the Yellow River and the Mt. Tai. A PM 2.5 sampling instrument was installed on the rooftop of the library ( $\sim 30 \mathrm{~m}$ above the ground) in the Shandong University (Central campus, $36^{\circ} 40^{\prime} 25^{\prime \prime} \mathrm{N}, 117^{\circ} 03^{\prime} 15^{\prime \prime} \mathrm{E}$ ), Jinan. The sampling site is located in a prosperous commercial street with convenient transportation and dense population, which provides the exposure information of the population to $\mathrm{PM}_{2.5}$ in Jinan. $\mathrm{PM}_{2.5}$ samples were collected from 7 to 30 January, 2016, using a medium-volume sampling instrument $(\mathrm{KC}-120 \mathrm{H}$, Qingdao Laoshan Company, China) coupled with prebaked quartz fiber filters $\left(8 \mathrm{~h}, 450^{\circ} \mathrm{C}\right)$. Each sample -lasted for $11.8 \mathrm{~h}$ and collected from 8:00 to 19:50 for daytime or 20:00 to 7:50 of the nest day for nighttime. Before and after the sampling campaign, the field blanks were collected by setting a filter onto the instrument for $15 \mathrm{~min}$ when the sampler was out of operation. A total of 47 ( 22 for daytime, 23 for nighttime, and 2 field blanks) samples were gained during the whole observation campaign. All the samples were sealed in aluminum foil bags and then stored in a freezer $\left(-20^{\circ} \mathrm{C}\right)$ before the experimental analysis. The meteorological parameters during the observation episode were obtained from the website of platform for monitoring and analysis of air quality in China (http://www.aqistudy.cn). 


\subsection{Chemical Analysis}

The analytical methods of OAs in $\mathrm{PM}_{2.5}$ were introduced in our previous research (Yi et al., 2021). Briefly, $1 / 4$ sample was extracted with mixed solution of methanol and dichloromethane $(1: 2 \mathrm{v} / \mathrm{v})$ under ultrasonication for $15 \mathrm{~min}$ (thrice). Then, the samples were concentrated under vacuum states and then dried by $\mathrm{N}_{2}$ (purity $>99.99 \%$ ). At $70^{\circ} \mathrm{C}$, the sample reacted with mixture of pyridine and N,O-bis-(trimethylsilyl) trifluoroacetamide (BSTFA) $(1: 5, v / v)(60 \mu \mathrm{L})$ for $3 \mathrm{~h}$. Finally, the samples were detected using a 7890A GC coupled with 5977B MSD (Agilent). The recoveries of target organic components were from $83 \%$ to $110 \%$.

Organic carbon (OC), elemental carbon (EC) were determined by DRI Model 2015 Carbon Analyzer with IMPROVE_A protocol (Chow et al., 2007). In short, the samplers were stepwise heated to $140,280,480$, and $580^{\circ} \mathrm{C}$ in pure He atmosphere to determine OC concentrations, and 580,740 , and $840^{\circ} \mathrm{C}$ in $98 \% \mathrm{He} / 2 \% \mathrm{O}_{2}$ atmosphere to test the concentrations of EC. Pyrolyzed carbon evolved from the time that the gas flow is changed from $\mathrm{He}$ only to $98 \% \mathrm{He} / 2 \% \mathrm{O}_{2}$ gas at $580^{\circ} \mathrm{C}$ to the time that the laser-measured filter transmittance reaches its initial value.

\subsection{Backward Trajectories Analysis}

The 72-hr and $100 \mathrm{~m}$ high air mass back-trajectories were calculated using the HYSPLIT model (https://www.arl.noaa.gov/). The PSCF was calculated to confirm potential source areas which contributed to the high concentrations of $\mathrm{PM}_{2.5}$ (Wang et al., 2009). The equation can be defined as follows:

$$
P S C F_{i j}=\frac{m_{i j}}{n i j}
$$

where $n_{i j}$ denotes the number of endpoints cross the $i j$ grid cell $\left(0.5^{\circ} \times 0.5^{\circ}\right.$ in this study) and $m_{i j}$ is the value where the endpoints of the trajectory concentrated in the same cell exceeding the determined threshold criterion value $\left(75 \mu \mathrm{g} \mathrm{m}^{-3}\right)$.

Concentration-weight trajectory (CWT) analysis has an advantage to distinguish the pollutants level of different trajectories (Wei et al., 2019). The CWT can be calculated as:

$$
C_{i j}=\frac{\sum_{l=1}^{M} C_{l} \tau_{i j l}}{\sum_{l=1}^{M} \tau_{i j l}}
$$

where $C_{i j}$ is the mean weight concentration on the grid cell $i j, C_{l}$ is the concentration corresponding to trajectory / arriving grid $i j, \tau_{i j l}$ is the detention time of trajectory $/$ in grid cell $i j$. In this study, both the PSCF and CWT algorithms were calculated using the MeteolnfoMap software with TrajStat plugins (Wang et al., 2009), which had been proved as an effective approach to determining the potential source areas of pollutant (Wei et al., 2019).

\section{RESULTS AND DISCUSSION}

\subsection{General Descriptions of Carbonaceous Species in $\mathrm{PM}_{2.5}$}

The temporal variations of $\mathrm{PM}_{2.5}, \mathrm{OC}$ and $\mathrm{EC}$ are presented in Fig. 1 along with the temperature $(T)$, relative humidity $(\mathrm{RH})$, and wind speed (WS). The mean concentrations of $\mathrm{PM}_{2.5}$ during the whole sampling campaign was $114.4 \pm 56.9 \mu \mathrm{g} \mathrm{m}^{-3}$, being higher than those in the corresponding period in Beijing $\left(54.3 \mu \mathrm{g} \mathrm{m}^{-3}\right)$, Tianjin $\left(60.8 \mu \mathrm{g} \mathrm{m}^{-3}\right)$, and Shijiazhuang $\left(104.6 \mu \mathrm{g} \mathrm{m}^{-3}\right)$ in Northern China (http://www.aqistudy.cn), suggesting that air pollution in Jinan was severe. It is noteworthy that the concentration of $\mathrm{PM}_{2.5}$ decreased by $44.2 \%$ compared to those reported in 2012 $\left(204.9 \mu \mathrm{g} \mathrm{m}^{-3}\right.$ ) (Yang et al., 2012), suggesting that the air quality in Jinan has become better in recent ten years, although the city still experienced severe air pollution. The difference ( $t$ test, $p>$ $0.05)$ on $\mathrm{PM}_{2.5}$ concentrations between day $\left(112.7 \pm 55.4 \mu \mathrm{g} \mathrm{m}^{-3}\right)$ and night $\left(116.0 \pm 58.3 \mu \mathrm{g} \mathrm{m}^{-3}\right)$ in the whole sampling period was negligible, indicating the minor impact of boundary layer heights. 


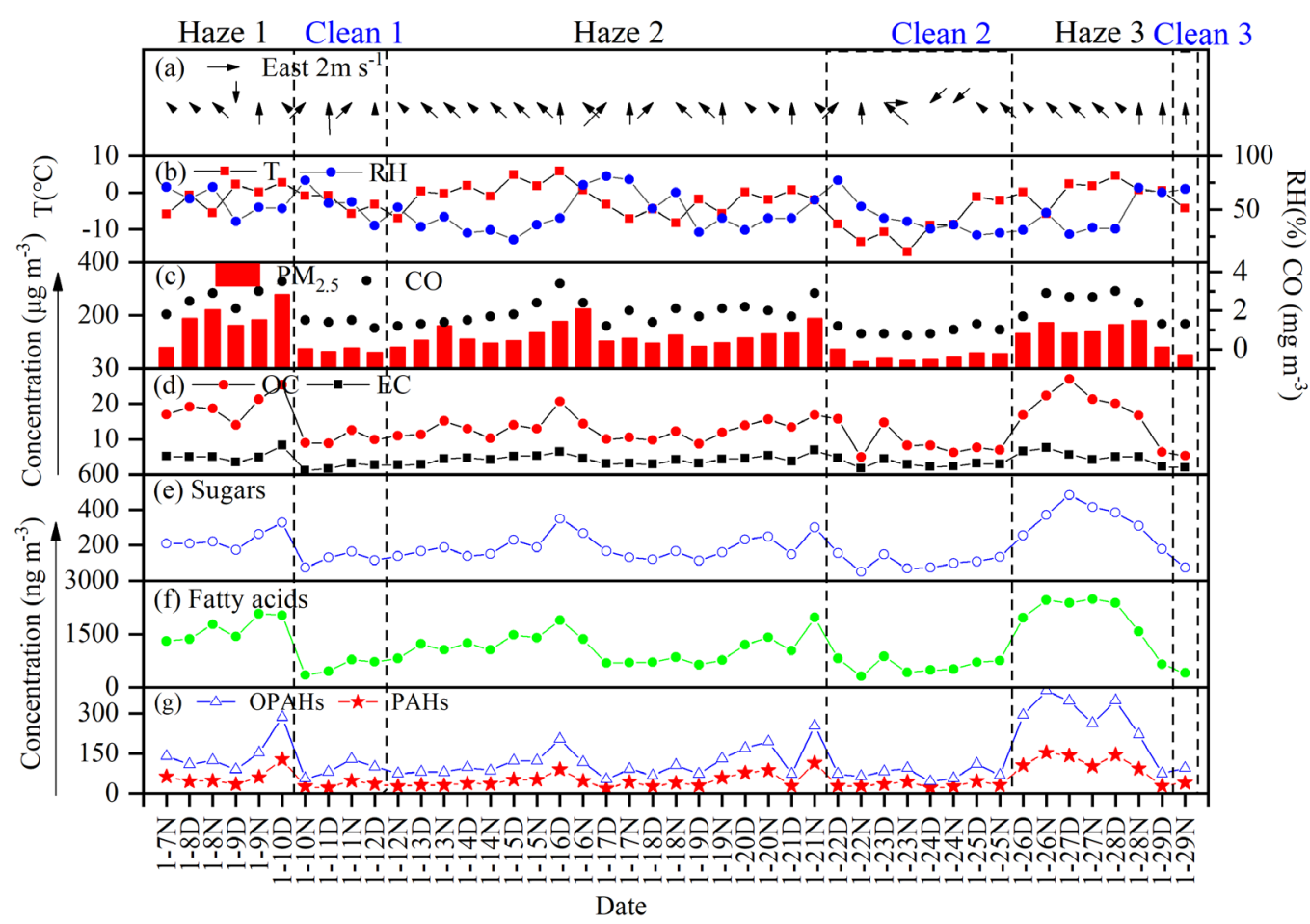

Fig. 1. Temporal variation of meteorological parameters (e.g., T, RH, and wind speed), the concentrations of $\mathrm{PM}_{2.5}$ and organic compounds during the whole sampling period.

According to $\mathrm{WHO}$, the air quality guideline value is $25 \mu \mathrm{g} \mathrm{m}^{-3}$ for $24-\mathrm{hr}$ mean concentration (http://www.who.int). However, the daily $\mathrm{PM}_{2.5}$ concentration higher than $25 \mu \mathrm{g} \mathrm{m}^{-3}$ was only observed in one sample in this study. Thus, the haze day was defined as the $\mathrm{PM}_{2.5}$ concentration larger than the $75 \mathrm{\mu g} \mathrm{m}^{-3}$ (Chinese National Ambient Air Quality Standard, Grade II, (NAAQS)), while the clean day was defined as the $\mathrm{PM}_{2.5}$ concentration lower than $75 \mu \mathrm{g} \mathrm{m}^{-3}$. A total of 45 samples were collected in Jinan, including 13 clean days and 32 haze days. $\mathrm{PM}_{2.5}$ during haze periods was $139.7 \pm 47.2 \mu \mathrm{g} \mathrm{m}^{-3}$, which was 2.7 times higher than that $\left(52.0 \pm 16.5 \mu \mathrm{g} \mathrm{m}^{-3}\right)$ during clean periods. As a reliable primary combustion emission tracer (Zhang et al., 2021), CO exhibited strong positive correlations $\left(R^{2}=0.77\right)$ (Fig. S1) with $\mathrm{PM}_{2.5}$ concentration. The concentration of $\mathrm{CO}$ increased dramatically from $1.1 \pm 0.3 \mathrm{mg} \mathrm{m}^{-3}$ during clean periods to $2.2 \pm 0.6 \mathrm{mg} \mathrm{m}^{-3}$ during haze periods, suggesting the significant effect of primary combustion on the haze formation in winter. The $\mathrm{PM}_{2.5}$ concentration decreased dramatically by $61.6 \%$ when a snowfall event occurred in the beginning of Clean2 period (21-22 January, 2016), which could attributed to the removal effect of wet deposition. The value was similar to the result about the effect of rain in Jinan (14\%-55\%) (Tian et al., 2021). Therefore, the more severe $\mathrm{PM}_{2.5}$ pollution in haze periods can be attributed to the stagnant meteorological and the enhanced emission of air pollutants (Table 1 and Fig. 1).

EC is directly emitted from the incomplete combustion of fossil fuels and biomass (Shi et al., 2021). OC is not only from the primary emissions, but also is from the atmospheric chemical reactions (Zhang et al., 2014). A strong correlation between OC and $\mathrm{EC}\left(R^{2}=0.70\right.$, Fig. 2) has been found in this study, suggesting that both species had similar emission sources. As depicted in Fig. 1, the OC and EC concentrations, and OC/EC ratios did not exhibit significant difference ( $t$ test, $P<0.01$ ) between day and night. The OC and EC average concentrations in Jinan in haze periods were 1.8 times more $\left(30.6 \pm 9.6 ; 9.4 \pm 2.8 \mu \mathrm{g} \mathrm{m}^{-3}\right)$ than those $\left(17.2 \pm 5.8 ; 5.1 \pm 1.8 \mu \mathrm{g} \mathrm{m}^{-3}\right)$ in clean days. Previous studies confirmed that OC/EC ratios in the aerosols emitted from biomass burning, coal combustion, and vehicles, were 9.0, 2.7, and 1.1, respectively (Li et al., 2014). The mean OC/EC ratio was $3.3 \pm 0.7$ in haze days, which was slightly lower than that $(3.6 \pm 1.5)$ in clean days, indicating that coal combustion was an important contributor in the atmosphere of Jinan. In addition, the higher OC/EC ratios in clean periods were mainly because of the enhanced formation of SOA. The OC/EC ratio can be applied to distinguish the presence of the secondary 
Table 1. Concentrations of organic compounds and meteorological parameters in the wintertime atmosphere of Jinan in 2016.

\begin{tabular}{|c|c|c|c|c|c|}
\hline & $\begin{array}{l}\text { Daytime } \\
(n=22)\end{array}$ & $\begin{array}{l}\text { Nighttime } \\
(n=23)\end{array}$ & $\begin{array}{l}\text { Clean periods } \\
(n=13)\end{array}$ & $\begin{array}{l}\text { Haze periods } \\
(n=32)\end{array}$ & $\begin{array}{l}\text { Total } \\
(n=45)\end{array}$ \\
\hline \multicolumn{6}{|c|}{ I. Meteorological parameters and gas pollutants } \\
\hline $\mathrm{T}$ & $-4.2 \pm 4.7$ & $-4.2 \pm 4.6$ & $-6.6 \pm 4.8$ & $-1.0 \pm 3.6$ & $-2.6 \pm 4.8$ \\
\hline $\mathrm{RH}$ & $52.5 \pm 15.6$ & $53.3 \pm 15.7$ & $48.2 \pm 17.2$ & $47.9 \pm 16.7$ & $48.0 \pm 16.9$ \\
\hline WS & $3.7 \pm 0.7$ & $3.7 \pm 0.8$ & $4.0 \pm 1.1$ & $3.5 \pm 1.0$ & $3.6 \pm 1.1$ \\
\hline $\mathrm{NO}_{2}\left(\mu \mathrm{g} \mathrm{m}^{-3}\right)$ & $68.4 \pm 22.7$ & $69.0 \pm 22.4$ & $38.2 \pm 12.7$ & $78.8 \pm 19.9$ & $67.1 \pm 25.9$ \\
\hline $\mathrm{CO}\left(\mathrm{mg} \mathrm{m}^{-3}\right)$ & $1.8 \pm 0.8$ & $1.9 \pm 0.7$ & $1.1 \pm 0.3$ & $2.2 \pm 0.6$ & $1.9 \pm 0.7$ \\
\hline \multicolumn{6}{|c|}{ II. Organic species $\left(\mathrm{ng} \mathrm{m}^{-3}\right)$} \\
\hline Levoglucosan & $140 \pm 75.5$ & $136 \pm 69.7$ & $69.1 \pm 25.3$ & $166 \pm 66.8$ & $138 \pm 72.6$ \\
\hline anhydrosugars & $176 \pm 98.7$ & $172 \pm 90.6$ & $85.4 \pm 30.7$ & $210 \pm 88.0$ & $174 \pm 94.7$ \\
\hline Primary sugars & $17.9 \pm 14.0$ & $13.8 \pm 7.8$ & $16.8 \pm 17.6$ & $15.4 \pm 7.6$ & $15.8 \pm 11.5$ \\
\hline Sugar alcohols & $6.3 \pm 2.4$ & $5.2 \pm 1.9$ & $4.8 \pm 2.8$ & $6.1 \pm 1.8$ & $5.7 \pm 2.2$ \\
\hline Saccharides & $200 \pm 101$ & $191 \pm 95.2$ & $107 \pm 35.8$ & $231 \pm 92.5$ & $195 \pm 98.1$ \\
\hline$C_{18: 0}$ & $264 \pm 118$ & $235 \pm 119$ & $150 \pm 56$ & $290 \pm 115$ & $249 \pm 119$ \\
\hline$C_{18: 1}$ & $80.3 \pm 58.0$ & $124 \pm 132$ & $33.1 \pm 17.7$ & $131 \pm 112$ & $103 \pm 105$ \\
\hline LFAs & $497 \pm 233$ & $496 \pm 304$ & $266 \pm 89.3$ & $590 \pm 265$ & $496 \pm 271$ \\
\hline HFAs & $696 \pm 371$ & $657 \pm 372$ & $312 \pm 108$ & $824 \pm 338$ & $676 \pm 372$ \\
\hline Fatty acids & $1193 \pm 590$ & $1152 \pm 644$ & $578 \pm 189$ & $1414 \pm 567$ & $1172 \pm 618$ \\
\hline $\mathrm{PAHs}$ & $54.6 \pm 39.9$ & $56.2 \pm 32.1$ & $32.8 \pm 8.7$ & $64.6 \pm 38.9$ & $55.4 \pm 36.2$ \\
\hline OPAHs & $81.0 \pm 54.7$ & $78.8 \pm 47.2$ & $48.3 \pm 16.3$ & $92.7 \pm 54.6$ & $79.9 \pm 51.0$ \\
\hline \multicolumn{6}{|c|}{ III. Other species $\left(\mu \mathrm{g} \mathrm{m}^{-3}\right)$} \\
\hline $\mathrm{PM}_{2.5}$ & $113 \pm 55.4$ & $116 \pm 58.3$ & $52.0 \pm 16.5$ & $140 \pm 47.2$ & $114 \pm 56.9$ \\
\hline $\mathrm{OC}$ & $27.9 \pm 11.1$ & $26.1 \pm 10.0$ & $17.2 \pm 5.1$ & $30.6 \pm 9.4$ & $26.9 \pm 10.6$ \\
\hline EC & $8.3 \pm 3.3$ & $8.1 \pm 3.1$ & $5.1 \pm 1.8$ & $9.4 \pm 2.8$ & $8.2 \pm 3.2$ \\
\hline OC/EC & $3.4 \pm 0.7$ & $3.4 \pm 1.1$ & $3.6 \pm 1.5$ & $3.3 \pm 0.7$ & $3.4 \pm 1.0$ \\
\hline
\end{tabular}

organic carbon (SOC) when the ratio exceeds 2.0 (Yang et al., 2012). The ratios of OC/EC fluctuated between 2.4 and 7.6, with an average of $3.4 \pm 1.0$ in the whole sampling period, indicating that large amounts of SOC were likely formed in Jinan. In this study, the concentration of SOC was estimated using the following Eq. (3) (Wang et al., 2010):

$\mathrm{SOC}=\mathrm{OC}-\mathrm{EC} \times(\mathrm{OC} / \mathrm{EC})_{\min }$

where $(O C / E C)_{\min }$ refers to the minimum value of detected $O C / E C$ during the sampling period. The SOC concentrations were $5.1 \mu \mathrm{g} \mathrm{m}^{-3}$ and $7.9 \mu \mathrm{g} \mathrm{m}^{-3}$ in clean and haze days, accounting for $29.5 \%$ and $25.7 \%$ of the OC, respectively, implying that the SOC was an important contributor of $\mathrm{PM}_{2.5}$ in Jinan and the secondary pollution was more serious in clean periods. A previous study in Handan of China during the wintertime haze events also found that the relative abundance of SOC in ambient aerosol increased with the decreased $\mathrm{PM}_{2.5}$ concentrations (Yang et al., 2018), largely because the high density of particles in the troposphere blocked solar radiation from reaching the ground layer and reduced the SOC generation rate (Tian et al., 2014).

\subsection{Concentrations and Variations of Organic Molecular Composition}

\subsubsection{Saccharides}

Ten kinds of sugar were determined in $\mathrm{PM}_{2.5}$ in Jinan (Fig. 3(a)). The total sugars concentrations were $107.0 \pm 35.8 \mathrm{ng} \mathrm{m}^{-3}$ and $231.3 \pm 92.5 \mathrm{ng} \mathrm{m}^{-3}$ in clean days and haze days, respectively (Table 1 ). As an important indicator of biomass burning, levoglucosan was observed to be the dominant sugar (Table 1). The levoglucosan concentration in haze days $\left(165.6 \pm 66.8 \mathrm{ng} \mathrm{m}^{-3}\right)$ was 2.4 higher than that $\left(69.1 \pm 25.3 \mathrm{ng} \mathrm{m}^{-3}\right)$ in clean days, contributed to $71.6 \%$ and $64.6 \%$ of the detected saccharides, respectively. The higher concentration and relative contributions of levoglucosan were largely because of the enhanced biomass burning activities in the surrounding regions and adverse meteorological conditions (Fig. S2). Levoglucosan exhibited close correlations with OC 


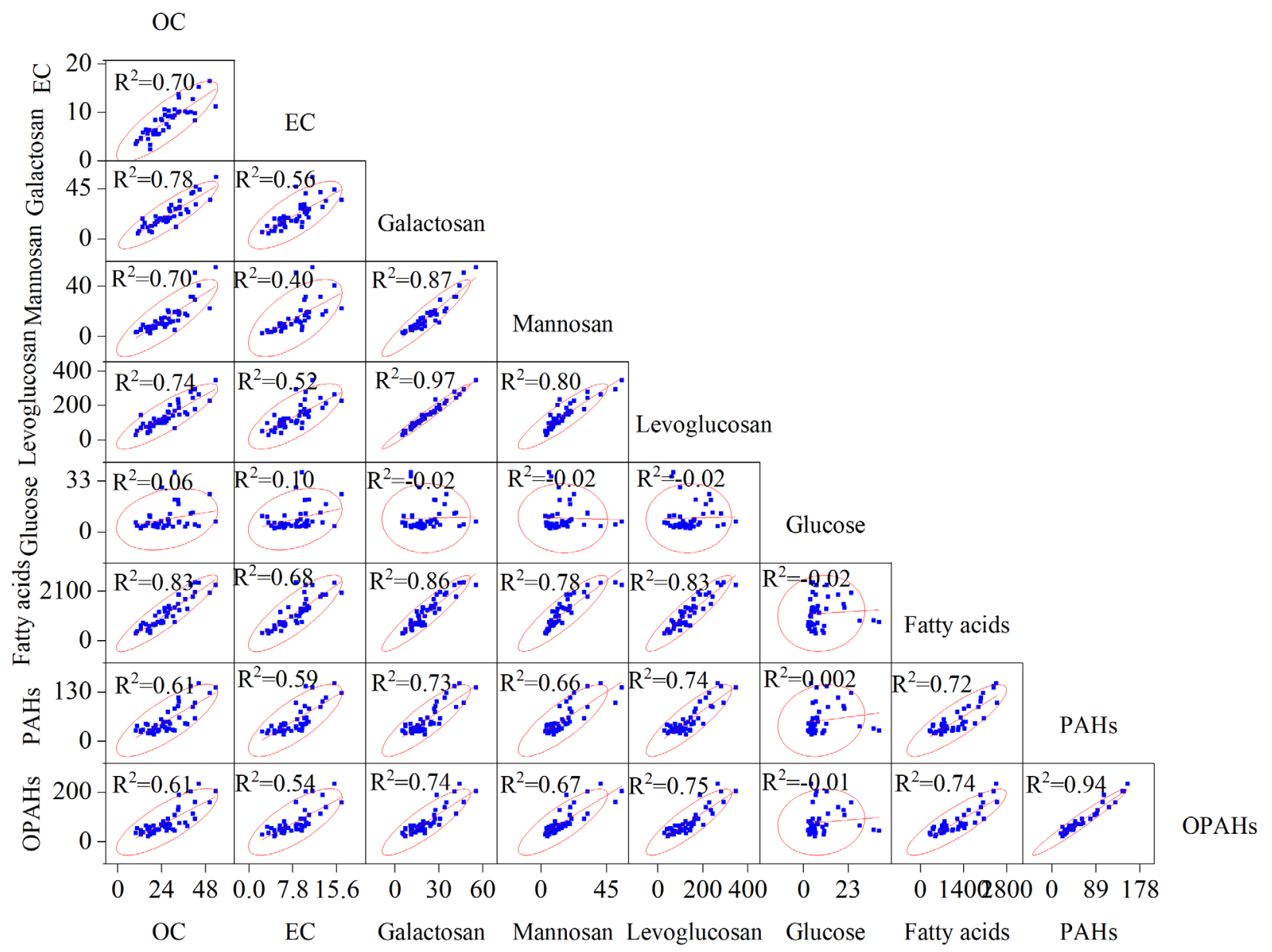

Fig. 2. Liner regressions of $\mathrm{OC}, \mathrm{EC}$, and major organic components in $\mathrm{PM}_{2.5}$.

and EC $\left(R^{2}>0.50\right.$, Fig. 2$)$, suggested the important role of biomass burning in the concentrations of carbonaceous species in Jinan. As the isomers of levoglucosan, galactosan and mannosan also can be proposed as the key tracers for biomass burning (Li et al., 2012; Yi et al., 2021). In this study, both species were robustly correlated with levogluscosan $\left(R^{2}>0.80\right)$. As shown in Fig. 1 , the three kinds of anhydrosugars concentrations were highest in haze periods, again indicating that the aerosols in haze days was greatly affected by biomass burning. Previous researches have confirmed that the ratio of levoglucosan/mannosan (L/M) was lower (3-7) for softwood burning and higher $(>10)$ for hardwood and crop residue burning (Fu et al., 2014; Zhang et al., 2015). In the whole sampling period, L/M ratios varied from 5.8 to 23.1 with an average of 10.8 , implying that the aerosols from biomass burning were closely related to the combination of softwood, hardwood, and/or crop residue burning.

The relative abundance of both primary sugars and sugar alcohols in total saccharides was $15.7 \%$ in Jinan aerosols (Fig. 3(a)). As shown in Fig 3, the dominant primary saccharide was glucose. Glucose was originated from multiple sources such as resuspension of surface soil, biomass burning, and biological particles. In this study, glucose did not show any correlation with levoglucosan $\left(R^{2}<\right.$ 0.01 ), confirmed the minor effect of biomass burning on glucose. Trehalose is a good tracer for dust emissions form Gobi areas, because it is only abundant in highly desiccation-tolerant plants (Wang et al., 2012). The trehalose concentration during the haze periods $\left(0.7 \pm 0.2 \mathrm{ng} \mathrm{m}^{-3}\right)$ was around one half of that $\left(1.3 \pm 1.4 \mathrm{ng} \mathrm{m}^{-3}\right)$ during the clean periods, indicating that the atmospheric pollutants in haze days were less influence by long-distance transport from Gobi deserts. Sucrose is the predominant constituent of airborne pollen grains (Fu et al., 2012), which exerts a major influence on plant flowering process. The concentration of sucrose was much higher in daytime $\left(2.5 \pm 1.9 \mathrm{ng} \mathrm{m}^{-3}\right)$ than that in nighttime $\left(1.5 \pm 0.7 \mathrm{ng} \mathrm{m}^{-3}\right)$, indicating the stronger biological activities during daytime than nighttime. 


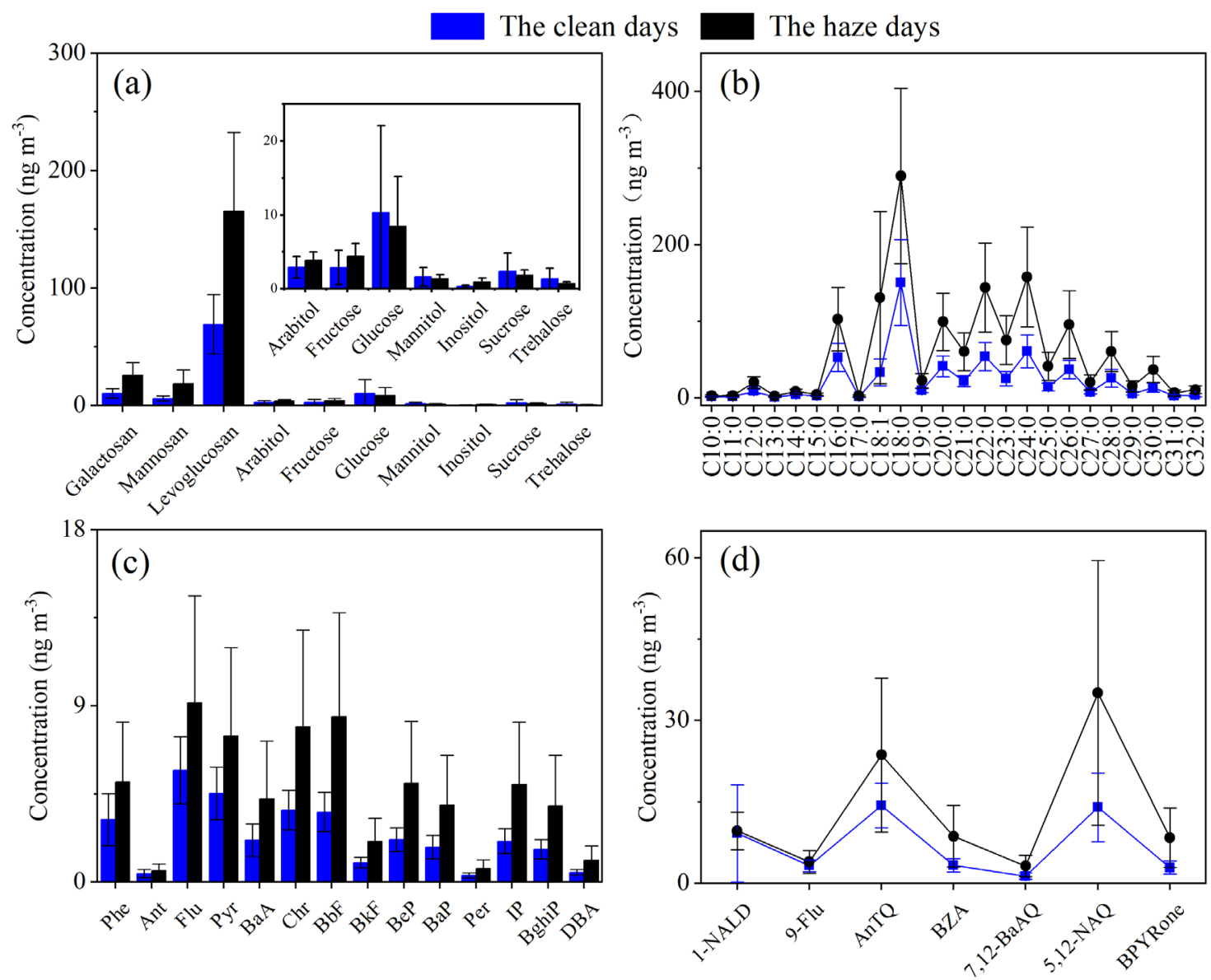

Fig. 3. Difference in the concentrations of (a) saccharides, (b) fatty acids, (c) PAHs, and (d) OPAHs in PM2.5 between during clean and haze periods.

\subsubsection{Fatty acids}

As shown in Table 1 and Fig. $3(b)$, fatty acids $\left(C_{10: 0}-C_{18: 0}, C_{18: 1}, C_{19: 0}-C_{32: 0}\right)$ were the predominant species in the detected organic compounds. The average concentrations of all fatty acids were $1172.1 \pm 618.3 \mathrm{ng} \mathrm{m}^{-3}$ during the entire observation period. The fatty acids concentration was 2.4 times higher in haze days $\left(1413.5 \pm 566.9 \mathrm{ng} \mathrm{m}^{-3}\right)$ than that $\left(578.0 \pm 189.2 \mathrm{ng} \mathrm{m}^{-3}\right)$ in clean days. The saturated fatty acids had maxima at $C_{18: 0}$ and $C_{24: 0}$ and exhibited a robust even carbon number dominance. Low molecular weight (LMW) fatty acids $\left(\mathrm{C}_{10: 0}-\mathrm{C}_{19: 0}\right)$ are largely from cooking activity, plants, and microbe, whereas high molecular weight (HMW) fatty acids $\left(\mathrm{C}_{20: 0}-\mathrm{C}_{32: 0}\right)$ are mostly originated from terrestrial higher plant waxes (Fu et al., 2008; Li et al., 2013; Liu et al., 2019). Carbon preference index (CPI, the concentration ratios of even/odd carbon for $\mathrm{C}_{20}-\mathrm{C}_{30}$ fatty acids) is a reliable method to distinguish anthropogenic or biogenic sources (Fu et al., 2008). The CPI value near to one can be regarded as the fossil fuel combustion source, but the value higher than five can be proposed to be largely originated from higher plant wax emissions (Fan et al., 2020). The CPI values were 3.2 in clean days and 2.8 in haze days, reflecting that the fatty acids were influenced by fossil fuel combustion source in the aerosols of Jinan. Previous research on field burning of crop residues found that the concentration of fatty acids was significantly enhanced in biomass burning period (Li et al., 2019a). Fatty acids concentration presented a robust correlation $\left(R^{2}=0.83\right)$ with levoglucosan in all samples (Fig. 2), implied the important contributor of biomass burning on the concentration of fatty acids. $\mathrm{C}_{18: 1}$ is unstable and prone to photochemical degradation comparing to $C_{18: 0}$, so the $C_{18: 1} / C_{18: 0}$ ratio is used to evaluate the level of oxidation (Wang et al., 2006). Two times higher of the ratio $(0.45 \pm 0.24)$ in haze days was observed than that $(0.22 \pm 0.09)$ in clean days, indicating that the photochemical degradation of unsaturated fatty acids was enhanced in clean periods. 


\subsubsection{PAHs and OPAHs}

Concentrations and variations of PAHs and OPAHs in different periods

PAHs are mainly derived from the incomplete combustions of biomass and fossil fuels (Li et al., 2017b; Liu et al., 2019; Yi et al., 2021). The total concentrations of 14 kinds of PAHs fluctuated between 18.3 and $152.8 \mathrm{ng} \mathrm{m}^{-3}$ (average: $55.4 \pm 36.2 \mathrm{ng} \mathrm{m}^{-3}$ ), which was comparable to the observed in Beijing ( $53.8 \mathrm{ng} \mathrm{m}^{-3}$ ) and Xi'an $\left(87 \mathrm{ng} \mathrm{m}^{-3}\right.$ ), but was 79.1 times more than that in Qinghai Lake $\left(0.7 \pm 0.5 \mathrm{ng} \mathrm{m}^{-3}\right)$ (Li et al., 2013) and was 61.6 times more than that on Mt. Tai $\left(0.9 \pm 0.6 \mathrm{ng} \mathrm{m}^{-3}\right)$ of China (Yi et al., 2021). In addition, the PAHs concentration reported in this article was also higher than the southern cities such as Guangzhou $\left(23.7 \pm 18.4 \mathrm{ng} \mathrm{m}^{-3}\right)($ Li et al., 2006) and Nanchang $\left(22.5 \pm 8.5 \mathrm{ng} \mathrm{m}^{-3}\right.$ ) (Liu et al., 2016). High values of PAHs in Jinan could be attributed to the enhanced coal combustion for heating in winter (Wang et al., 2006). The PAHs concentration exhibited a strong correlation with levoglucosan $\left(R^{2}=0.74\right.$, Fig. 2$)$, which suggested that biomass burning was key source of PAHs in Jinan. The low temperature $\left(-3^{\circ} \mathrm{C}\right)$ (Fig. 1) in the winter could favor the gaseous PAHs partitioning into particle phase (Qiao et al., 2014; Liu et al., 2019). Fluoranthene (Flu) was the most abundant PAHs, followed by benzo(b)fluoranthesne (BbF), and chrysene (Chr) (Fig. 3(c)). The ratio of BaP/BeP could be employed to illustrate whether the aerosols are freshly emitted (higher than one) or aged (lower than one) (Li et al., 2019b). In this study, the average $\mathrm{BaP} / \mathrm{BeP}$ ratio was $0.79 \pm 0.09$, manifesting that $\mathrm{PAHs}$ in the $\mathrm{PM}_{2.5}$ samples had undergone an aging process. The total concentration of PAHs $\left(64.6 \pm 38.9 \mathrm{ng} \mathrm{m}^{-3}\right)$ during haze periods was 1.9 times more than that $\left(34.4 \pm 8.7 \mathrm{ng} \mathrm{m}^{-3}\right)$ during clean periods because of the effects of both enhanced emissions of human activities and unfavorable meteorological conditions. As shown in Fig. 4, 4ring was the dominant PAHs, followed by 6-ring and 3-ring (or 5-ring) during clean periods (or haze periods). LMW PAHs (3-ring and 4-ring) principally come from the coal and biomass combustion, while HMW PAHs (5-ring and 6-ring) were primarily originated from the vehicle exhausts (Yi et al. 2021). LMW PAHs accounted for $61.0 \%$ and $55.7 \%$ of the total PAHs concentration during clean and haze periods, respectively. The dominant of LMW PAHs illustrated the significant contribution of biomass and coal combustions to PAHs in this study. In addition, a possible mechanism for the dominance of LMW PAHs was that LMW PAHs under low temperatures condition were readily assembled in the particulate phase and lower boundary layer (Yi et al., 2021). The mean temperature in haze periods $\left(-1.0^{\circ} \mathrm{C}\right)$ was higher than that in clean periods $\left(-6.6^{\circ} \mathrm{C}\right)$. Thus, the higher $\mathrm{LMW} / \mathrm{HMW}$ PAHs ratio $(1.5 \pm 0.3)$ in clean days was obtained than that $(1.2 \pm 0.2)$ in haze days, again confirming that the lower temperature conditions favored the LMW PAHs transferring into particle phase due to the cold-trapping of PAHs. The driving role of gas-particle partitioning of PAHs was supported by the good correlation of T with HMW PAHs/LMW PAHs ratios $\left(R^{2}=0.49\right)$ (Fig. S3).

The mean concentration of total seven OPAHs was $79.9 \pm 51.0 \mathrm{ng} \mathrm{m}^{-3}$ in the entire sampling episodes (Fig. 3(d)). 5,12-Naphthacenequinone (NAQ, 36.3\%) was observed as the most abundant OPAHs, followed by 9,10-anthraquinone (ANTQ) (26.3\%), and 1-naphthaldehyde (NAD) (11.9\%) in all the day and night samples. The OPAHs concentration in Jinan was higher than in Guangzhou and Xi'an, China (Wei et al., 2012; Wang et al., 2016). The high OPAHs concentrations observed in North China could be attributed to the increased fuel combustions during the heating periods (Li et al., 2015). The higher emission factor of OPAHs from the combustion of biomass fuels in

(a) The clean periods

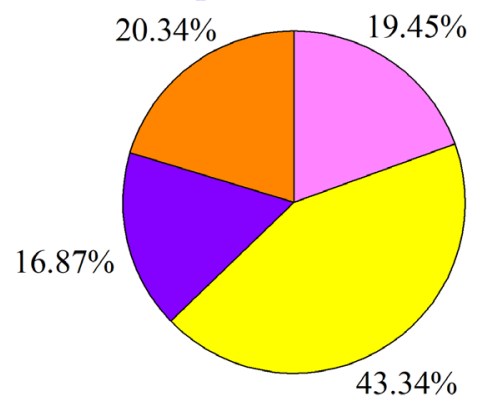

(b) The haze periods

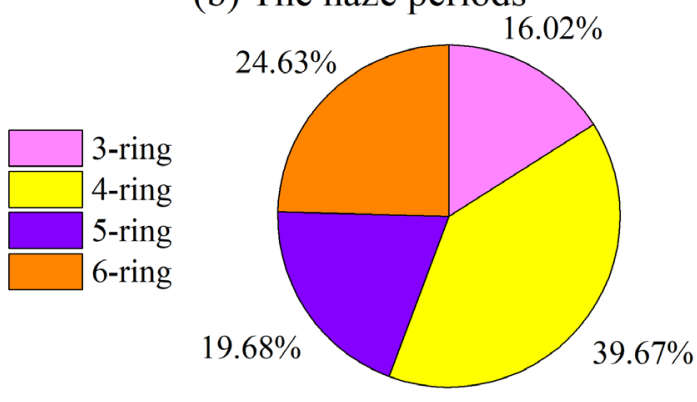

Fig. 4. Distribution of ring number of PAHs in $\mathrm{PM}_{2.5}$ collected in Jinan during (a) clean periods and (b) haze periods. 
residential stoves was obtained than that from the solid fuel combustions and motor vehicle exhausts (Shen et al., 2013; Li et al., 2015; Shen et al., 2015). As shown in Fig. 2, OPAHs exhibited a strong correlation with levoglucosan $\left(R^{2}=0.75\right)$, which indicated that biomass burning significantly contributed to OPAHs in Jinan. Moreover, OPAHs presented robust correlation with PAHs $\left(R^{2}=\right.$ 0.94) (Fig. 2), suggesting that OPAHs were either co-emitted with PAHs or derived from the secondary formation by radical reactions with PAHs in the environment. Around two times more OPAHs concentration $\left(92.7 \pm 54.6 \mathrm{ng} \mathrm{m}^{-3}\right)$ in haze periods was obtained than that $\left(48.3 \pm 16.3 \mathrm{ng} \mathrm{m}^{-3}\right)$ in clean periods. The values of OPAHs/parent-PAHs (PPAHs) can elucidate the secondary formation level of OPAHs from related PPAHs (Bandowe and Nkansah, 2016). Unlike above discussions of other atmosphere oxidation indicator (e.g., SOC/OC, $\mathrm{C}_{18: 1} / \mathrm{C}_{18: 0}$ ), the ratios of OPAHs/PAHs between clean and haze periods were equivalent (6.3) (Fig. S4). The mass ratio of OPAHs/PAHs in daytime $(7.3 \pm 1.4)$ was higher than that in nighttime $(5.4 \pm 1.5)$, which implied more photochemical formation of daytime OPAHs due to the stronger solar radiation and higher temperature. Previous studies have proved that the $\mathrm{BaAQ} / \mathrm{BaA}$ and $\mathrm{ANTQ} / \mathrm{ANT}$ ratios were in the range of $0.03-0.16$ and 0.14-0.89, respectively, indicating that they were freshly emitted from the combustion sources (Shen et al., 2011; Shen et al., 2012; Wang et al., 2016). The average values of BaAQ/BaA and ANTQ/ANT were $0.8 \pm 0.2$ and $40.7 \pm 9.3$, respectively, illustrating that the secondary production of OPAHs had essential effect on the aerosols in Jinan.

\section{Sources apportionment of PAHs by diagnostic ratios}

The ratios of Ant/(Ant + Phe), Flu/(Flu + Pyr), BaA/(BaA + Chr), and InP/(InP + BghiP) were calculated to differentiate different sources of PAHs (Fig. 5). The mass ratio of Ant/(Ant + Phe) higher than 0.1 is from the fossil fuel combustion, and the opposite is characteristic of petroleum (Wang et al., 2008; Yi et al. , 2021). The ratio of Ant/(Ant + Phe) ranged from 0.07 to 0.17, implying that petroleum (e.g., oil spilling and volatilization) and fossil fuel combustions were the major
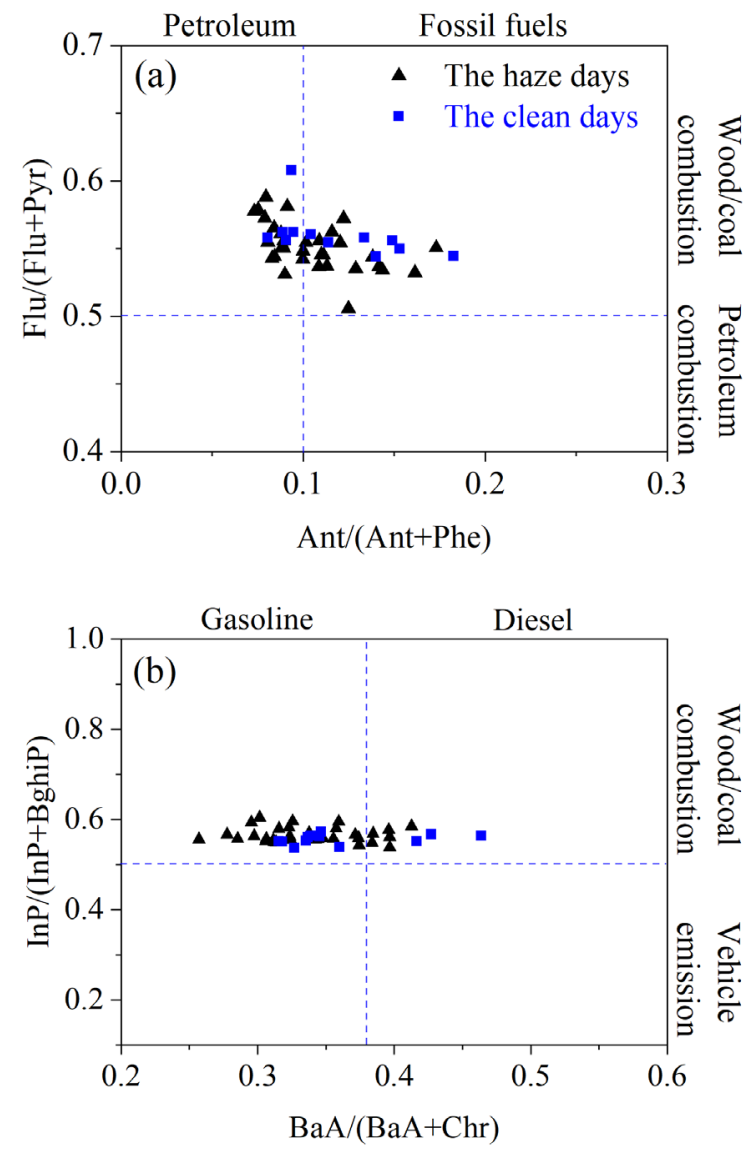

Fig. 5. Diagnostic ratios for the emissions sources of PAHs. (a) Ant/(Ant + Phe) and Flu/(Flu + Pyr); (b) $\mathrm{BaA} /(\mathrm{BaA}+\mathrm{Chr})$ and $\ln \mathrm{P} /(\operatorname{In} \mathrm{P}+$ Bghip) . 
sources of PAHs in Jinan. The ratio of Flu/(Flu + Pyr) was in the scope of 0.53 to 0.61 , suggested the important contribution of biomass burning or coal combustion. The $\mathrm{BaA} /(\mathrm{BaA}+\mathrm{Chr})$ ratio varied from 0.26 to 0.46 , falling into the scopes of diesel $(0.38-0.64)$ and gasoline $(0.22-0.55)$ emissions (Shi et al., 2014). The ratio of $\operatorname{InP} /(\operatorname{InP}+\mathrm{BghiP})$ is reported as $0.18,0.38$ and 0.50 for gasoline, diesel and mixture of coal and biomass combustion (Liu et al., 2019). The ratios fluctuated from 0.54 to 0.60 , implying that PAHs were mainly from combustions of coal and biomass. Based on above analysis, we concluded that biomass burning and coal combustions were the dominant sources of PAHs in the Jinan aerosols, despite a sharp rise in vehicle emissions in recent years. Thus, the Jinan government should do their best great efforts to reduce the consumption of coal and biomass to decrease urban PAHs concentrations.

\subsection{Sources Appointment}

\subsubsection{PMF}

To quantitatively estimate the sources of target organic components in $\mathrm{PM}_{2.5}$ in different episodes, PMF model was chosen in this study. Detailed introduce about PMF model has been published in a previous article (Manousakas et al., 2017). Fig. 6 illustrates the factor profiles resolved by the model for Jinan city.

In clean periods, the first factor was dominated by levoglucosan, followed by LMW and HMW fatty acids. Levoglucosan was a key tracer for biomass burning. Fatty acids also exhibited good correlation with levoglucosan as discussed above. Therefore, Factor 1 could be identified as biomass burning source, and the relative contribution of which was $45.1 \%$ in clean periods. Factor 2 was characterized by the high level of glucose. Glucose is mostly derived from soil resuspend and biological activities. Thus, Factor 2 could be defined as soil and plant emissions, accounting for $32.1 \%$. Factor 3 was dominated by LMW PAHs, HMW PAHs and OPAHs. PAHs and OPAHs are largely from the anthropogenic emissions (e.g., vehicle emissions and coal combustions), and OPAHs were mainly originated from secondary oxidation as discussed above. Thus, Factor 3 can be regarded as the combustions of fossil fuels and secondary formation, accounting for $22.8 \%$.

In haze periods, Factor 1 was dominated by EC, levoglucosan and fatty acids, which can be
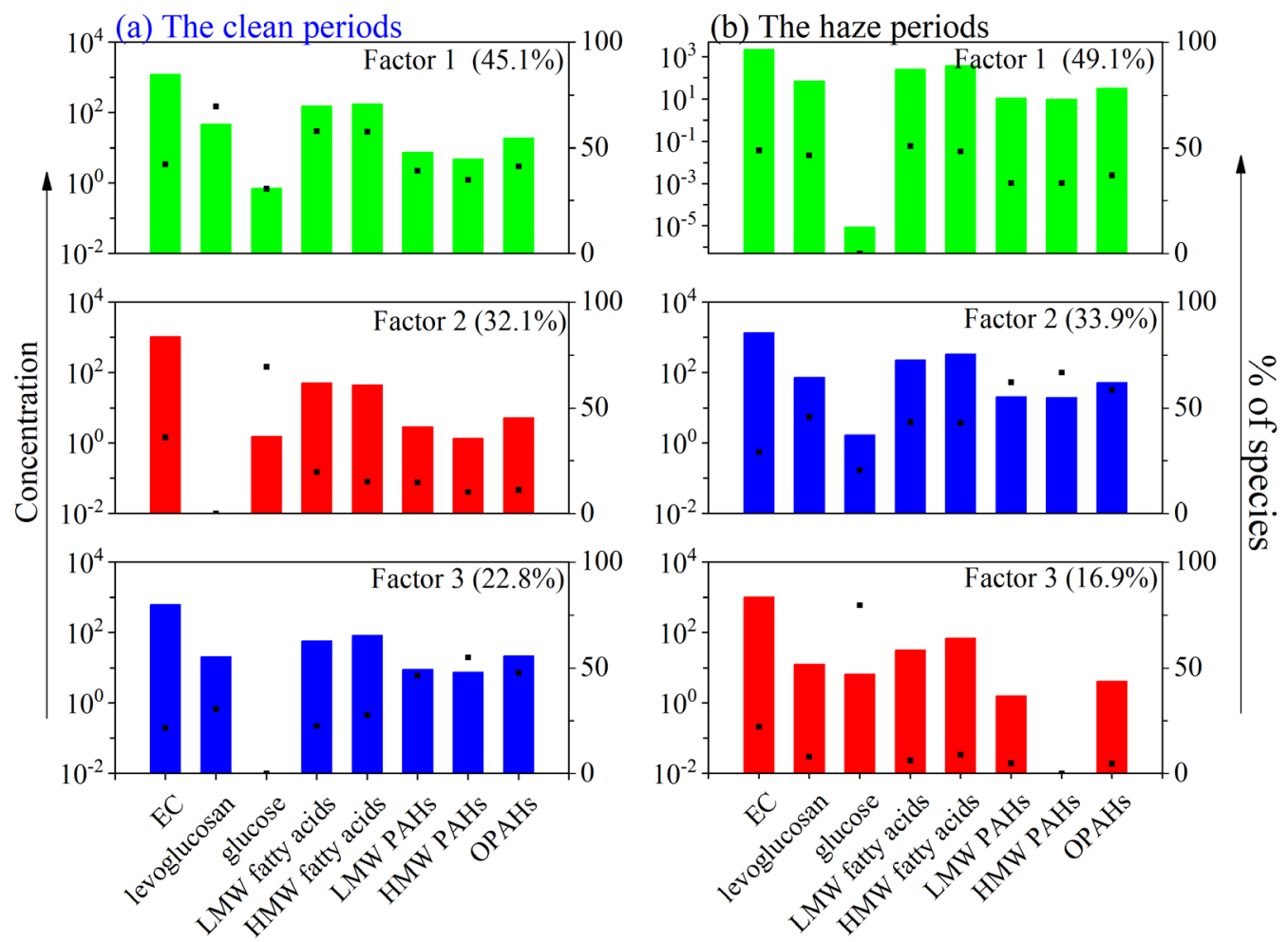

Fig. 6. Results of PMF for organic aerosols during (a) clean periods and (b) haze periods in $\mathrm{PM}_{2.5}$ in Jinan. 
considered as biomass burning. The higher values of LMW PAHs, HMW PAHs and OPAHs were obtained in Factor 2, which could be regarded as fossil fuel combustions and the secondary formation. Factor 3 was characterized by high contribution of glucose, which can be regarded as soil and plant emissions. The relative contribution in haze periods in Jinan was $49.1 \%$ for biomass burning (Factor 1), 33.9\% for fossil fuel combustions (Factor 2), and $16.9 \%$ for soil and plant emissions (Factor 3 ). These results again demonstrated the significant effect of biomass burning on the Jinan aerosols.

\subsubsection{PSCF and CWT}

Spatial distributions of potential source areas of $\mathrm{PM}_{2.5}$ and its major organic components in Jinan during winter are illustrated in Fig. 7. The darker colors represented the heavier contribution weight of the areas. The relatively high PSCF values for $\mathrm{PM}_{2.5}$ were largely distributed in the surrounding areas of the sampling site (Fig. 7(a)), such as Shandong Province and the BTH region, which indicated that air masses from these regions exerted an important influence on the haze occurrence in this region. The weaker PSCF values were distributed in Inner Mongolia and northern of Henan Province, suggesting that the effect of long-distance transport on $\mathrm{PM}_{2.5}$ was minor. The calculated CWT values also supported the result of PSCF. For PM2.5, the high CWT values (above $80 \mu \mathrm{g} \mathrm{m}^{-3}$ ) were observed in the BTH region and Shandong Province (Fig. 7(b)), indicating that the $\mathrm{PM}_{2.5}$ in Jinan city were principally derived from the surrounding regions.
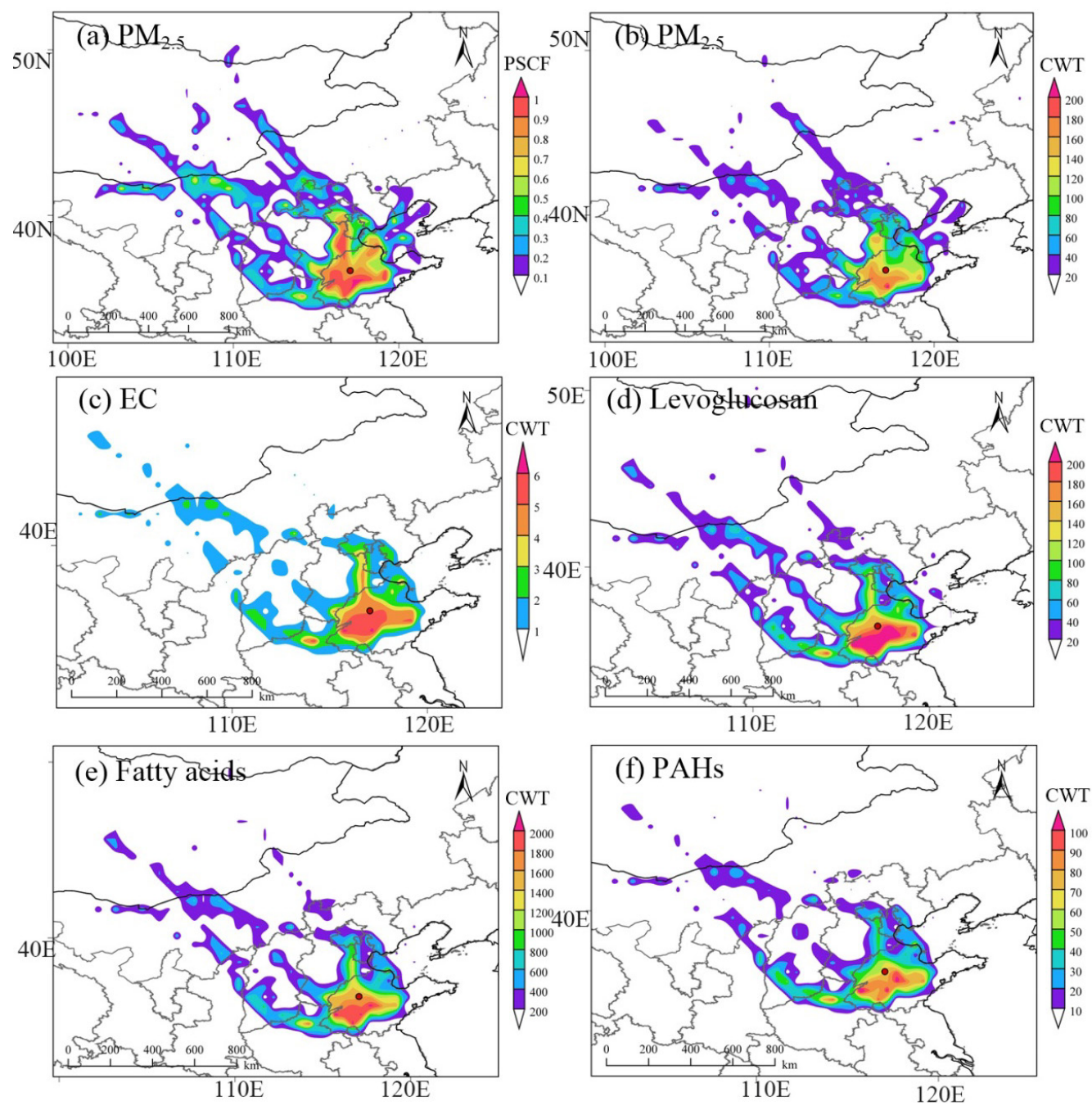

Fig. 7. (a) PSCF and (b) CWT values and spatial distribution of $P M_{2.5}$ during the whole sampling period. CWT values and spatial distribution of (c) EC, (d) levoglucosan, (e) fatty acids and (f) PAHs in haze periods. 
Potential source regions of the major organic components in $\mathrm{PM}_{2.5}$ during haze periods determined by the CWT model were listed in Figs. 7(c-f). During haze periods, the high CWT values for EC, levoglucosan, fatty acids and PAHs were mainly distributed in the Shandong Province. Several studies of source apportionment have used PSCF and CWT values to conclude that the Shandong Province was the major source region of EC and $\mathrm{PM}_{2.5}$ (Kim et al., 2018). As shown in Fig. 7(d), Shandong Province can be regarded as an important potential area for biomass burning in Northern China on account of high CWT values for levoglucosan. In general, the PSCF and CWT model indicated that Shandong Province was the important potential source region of organic compounds and $\mathrm{PM}_{2.5}$ in Jinan.

\section{CONCLUSIONS}

In recent years, China has suffered severe air pollution, especially in the NCP. To investigate the characteristic of $\mathrm{PM}_{2.5}$ pollution and the potential formation processes, $\mathrm{PM}_{2.5}$ samples were collected in Jinan, which is a typical polluted city in NCP. A total of 48 kinds of PM 2.5 -bound organic components including 10 saccharides, 24 fatty acids, and 14 PAHs during a wintertime haze period were analyzed. The $\mathrm{PM}_{2.5}$ concentration in haze periods $\left(139.7 \pm 47.2 \mu \mathrm{g} \mathrm{m}^{-3}\right)$ was 1.9 times higher than the NAAQS, Grade II limit $\left(75 \mu \mathrm{g} \mathrm{m}^{-3}\right)$, implying that Jinan was facing severe $\mathrm{PM}_{2.5}$ pollution in wintertime. The ratios of OC/EC and correlation analysis implied that OC was principally from the mixture of biomass burning and coal combustions. During haze days, the concentrations of saccharides, fatty acids and PAHs significantly increased, and those species were robustly correlated with levoglucosan $\left(R^{2}>0.7\right)$, suggesting that OAs in Jinan during the winter were highly affected by biomass burning. The $C_{18: 1} / C_{18: 0}$ ratio in clean days $(0.45 \pm 0.24)$ was higher than that in haze days $(0.22 \pm 0.09)$, suggesting that the aerosols were more oxidized in clean periods. Based on the results of PMF model, three source factors were identified. During clean periods, biomass burning $(45.1 \%)$ was the most dominant source, followed by soil and plant emissions (32.1\%), and fossil fuel combustion and secondary formation (22.8\%). However, the dominant source of OAs was biomass burning (49.1\%) during haze periods, followed by fossil fuel combustion and secondary formation (33.9\%), and soil and plant emissions (16.9\%). High PSCF and CWT values indicated that Shandong Province and BTH region were the major potential source regions of $\mathrm{PM}_{2.5}$. In addition, the CWT results showed that Shandong Province was the major source area of OAs in haze periods. Therefore, this study has an important contribution to understand the pollution characteristic and sources of Jinan aerosols, which can in turn deepen our comprehending of regional pollution in North China.

\section{ACKNOWLEDGMENTS}

This work was supported by the National Science Foundation of China (Grant Nos. 41505112 and 41702373), the Natural Science Foundation of Shandong Province (Grant No. ZR2020MD113), and the Open Funds of State Key Laboratory of Loess and Quaternary Geology, Institute of Earth Environment, Chinese Academy of Sciences (Grant No. SKLLQG2020).

\section{SUPPLEMENTARY MATERIAL}

Supplementary material for this article can be found in the online version at https://doi. $\operatorname{org} / 10.4209 /$ aaqr. 210180

\section{REFERENCES}

An, Z., Huang, R.J., Zhang, R., Tie, X., Li, G., Cao, J., Zhou, W., Shi, Z., Han, Y., Gu, Z., Ji, Y. (2019). Severe haze in northern China: A synergy of anthropogenic emissions and atmospheric processes. Proc. Natl. Acad. Sci. U.S.A. 116, 8657-8666. https://doi.org/10.1073/pnas.190012 5116

Ari, P.E., Ari, A., Dumanoğlu, Y., Odabasi, M., Gaga, E.O. (2020). Organic chemical characterization 
of size segregated particulate matter samples collected from a thermal power plant area. Environ. Pollut. 262, 114360. https://doi.org/10.1016/j.envpol.2020.114360

Bandowe, B.A.M., Nkansah, M.A. (2016). Occurrence, distribution and health risk from polycyclic aromatic compounds (PAHs, oxygenated-PAHs and azaarenes) in street dust from a major West African Metropolis. Sci. Total Environ. 553, 439-449. https://doi.org/10.1016/j.scitotenv.2016. 02.142

Chow, J.C., Watson, J.G., Chen, L.W.A., Chang, M.C.O., Robinson, N.F., Trimble, D., Kohl, S. (2007). The IMPROVE_A temperature protocol for thermal/optical carbon analysis: Maintaining consistency with a long-term database. J. Air Waste Manage. Assoc. 57, 1014-1023. https://doi.org/10.3155/1047-3289.57.9.1014

Fan, Y.B., Liu, C.Q., Li, L.J., Ren, L.J., Ren, H., Zhang, Z.M., Li, Q.K., Wang, S., Hu, W., Deng, J.J., Wu, L.B., Zhong, S.J., Zhao, Y., Pavuluri, C.M., Li, X.D., Pan, X.L., Sun, Y.L., Wang, Z.F., Kawamura, K., Shi, Z.B., Fu, P.Q. (2020). Large contributions of biogenic and anthropogenic sources to fine organic aerosols in Tianjin, North China. Atmos. Chem. Phys. 20, 117-137. https://doi.org/10.5 194/acp-20-117-2020

Fu, P., Kawamura, K., Okuzawa, K., Aggarwal, S.G., Wang, G., Kanaya, Y., Wang, Z. (2008). Organic molecular compositions and temporal variations of summertime mountain aerosols over Mt. Tai, North China Plain. J. Geophys. Res. 113, D19107 . https://doi.org/10.1029/2008jd009900

Fu, P.Q., Kawamura, K., Kobayashi, M., Simoneit, B.R.T. (2012). Seasonal variations of sugars in atmospheric particulate matter from Gosan, Jeju Island: Significant contributions of airborne pollen and Asian dust in spring. Atmos. Environ. 55, 234-239. https://doi.org/10.1016/j.atmos env.2012.02.061

Fu, P.Q., Kawamura, K., Chen, J., Miyazaki, Y. (2014). Secondary production of organic aerosols from biogenic VOCs over Mt. Fuji, Japan. Environ. Sci. Technol. 48, 8491-8497. https://doi.org/ 10.1021/es500794d

Gao, X., Yang, L., Cheng, S., Gao, R., Zhou, Y., Xue, L., Shou, Y., Wang, J., Wang, X., Nie, W., Xu, P., Wang, W. (2011). Semi-continuous measurement of water-soluble ions in $P_{2.5}$ in Jinan, China: Temporal variations and source apportionments. Atmos. Environ. 45, 6048-6056. https://doi.org/10.1016/j.atmosenv.2011.07.041

Hallquist, M., Wenger, J.C., Baltensperger, U., Rudich, Y., Simpson, D., Claeys, M., Dommen, J., Donahue, N.M., George, C., Goldstein, A.H., Hamilton, J.F., Herrmann, H., Hoffmann, T., linuma, Y., Jang, M., Jenkin, M.E., Jimenez, J.L., Kiendler-Scharr, A., Maenhaut, W., McFiggans, G., et al. (2009). The formation, properties and impact of secondary organic aerosol: Current and emerging issues. Atmos. Chem. Phys. 9, 5155-5236. https://doi.org/10.5194/acp-9-5155-2009

He, J.B., Fan, S.X., Meng, Q.Z., Sun, Y., Zhang, J., Zu, F. (2014). Polycyclic aromatic hydrocarbons (PAHs) associated with fine particulate matters in Nanjing, China: Distributions, sources and meteorological influences. Atmos. Environ. 89, 207-215. https://doi.org/10.1016/j.atmosenv.2 014.02.042

Ho, K.F., Ho, S.S.H., Lee, S.C., Kawamura, K., Zou, S.C., Cao, J.J., Xu, H.M. (2011). Summer and winter variations of dicarboxylic acids, fatty acids and benzoic acid in $\mathrm{PM}_{2.5}$ in Pearl Delta River Region, China. Atmos. Chem. Phys. 11, 2197-2208. https://doi.org/10.5194/acp-11-2197-2011

Huang, R.J., Zhang, Y.L., Bozzetti, C., Ho, K.F., Cao, J.J., Han, Y.M., Daellenbach, K.R., Slowik, J.G., Platt, S.M., Canonaco, F., Zotter, P., Wolf, R., Pieber, S.M., Bruns, E.A., Crippa, M., Ciarelli, G., Piazzalunga, A., Schwikowski, M., Abbaszade, G., Schnelle-Kreis, J., Zimmermann, R., An, Z.S., Szidat, S., Baltensperger, U., El Haddad, I., Prevot, A.S.H. (2014). High secondary aerosol contribution to particulate pollution during haze events in China. Nature 514, 218-222. https://doi.org/10.1038/nature13774

Kim, S., Kim, T.Y., Yi, S.M., Heo, J. (2018). Source apportionment of $\mathrm{PM}_{2.5}$ using positive matrix factorization (PMF) at a rural site in Korea. J. Environ. Manage. 214, 325-334. https://doi.org/ 10.1016/j.jenvman.2018.03.027

Kong, S., Li, X., Li, L., Yin, Y., Chen, K., Yuan, L., Zhang, Y., Shan, Y., Ji, Y. (2015). Variation of polycyclic aromatic hydrocarbons in atmospheric $\mathrm{PM}_{2.5}$ during winter haze period around 2014 Chinese Spring Festival at Nanjing: Insights of source changes, air mass direction and firework particle injection. Sci. Total Environ. 520, 59-72. https://doi.org/10.1016/j.scitotenv.2015.03.001

Lee, K.Y., Wong, C.K.C., Chuang, K.J., Bien, M.Y., Cao, J.J., Han, Y.M., Tian, L., Chang, C.C., Feng, P.H., Ho, K.F., Chuang, H.C. (2014). Methionine oxidation in albumin by fine haze particulate matter: 
An in vitro and in vivo study. J. Hazard. Mater. 274, 384-391. https://doi.org/10.1016/j.jhazma t.2014.04.029

Li, J., Wang, G., Aggarwal, S.G., Huang, Y., Ren, Y., Zhou, B., Singh, K., Gupta, P.K., Cao, J., Zhang, R. (2014). Comparison of abundances, compositions and sources of elements, inorganic ions and organic compounds in atmospheric aerosols from Xi'an and New Delhi, two megacities in China and India. Sci. Total Environ. 476-477, 485-495. https://doi.org/10.1016/j.scitotenv.2014.01.011

Li, J., Zhang, G., Li, X.D., Qi, S.H., Liu, G.Q., Peng, X.Z. (2006). Source seasonality of polycyclic aromatic hydrocarbons (PAHs) in a subtropical city, Guangzhou, South China. Sci. Total Environ. 355, 145-155. https://doi.org/10.1016/j.scitotenv.2005.02.042

Li, J., Wang, G., Zhou, B., Cheng, C., Cao, J., Shen, Z., An, Z. (2012). Airborne particulate organics at the summit (2060 m, a.s.l.) of Mt. Hua in central China during winter: Implications for biofuel and coal combustion. Atmos. Res. 106, 108-119. https://doi.org/10.1016/j.atmosres.2011.11.012

Li, J., Wang, G., Zhang, Q., Li, J., Wu, C., Jiang, W., Zhu, T., Zeng, L. (2019a). Molecular characteristics and diurnal variations of organic aerosols at a rural site in the North China Plain with implications for the influence of regional biomass burning. Atmos. Chem. Phys. 19, 10481-10496. https://doi.org/10.5194/acp-19-10481-2019

Li, J.J., Wang, G.H., Wang, X.M., Cao, J.J., Sun, T., Cheng, C.L., Meng, J.J., Hu, T.F., Liu, S.X. (2013). Abundance, composition and source of atmospheric $\mathrm{PM}_{2.5}$ at a remote site in the Tibetan Plateau, China. Tellus B 65, 20281. https://doi.org/10.3402/tellusb.v65i0.20281

Li, L.J., Ho, S.S.H., Feng, B.H., Xu, H.B., Wang, T., Wu, R.S., Huang, W., Qu, L.L., Wang, Q.Y., Cao, J.J. (2019b). Characterization of particulate-bound polycyclic aromatic compounds (PACs) and their oxidations in heavy polluted atmosphere: A case study in urban Beijing, China during haze events. Sci. Total Environ. 660, 1392-1402. https://doi.org/10.1016/j.scitotenv.2019.01.078

Li, M., Wu, L., Zhang, X., Wang, X., Bai, W., Ming, J., Geng, C. and Yang. W. (2020). Comparison of $\mathrm{PM}_{2.5}$ chemical compositions during haze and non-haze days in a heavy industrial city in north China. Aerosol Air Qual. Res. 20, 1950-1960. https://doi.org/10.4209/aaqr.2019.11.0591

Li, W., Wang, C., Shen, H.Z., Su, S., Shen, G.F., Huang, Y., Zhang, Y.Y., Chen, Y.C., Chen, H., Lin, N., Zhuo, S.J., Zhong, Q.R., Wang, X.L., Liu, J.F., Li, B.G., Liu, W.X., Tao, S. (2015). Concentrations and origins of nitro-polycyclic aromatic hydrocarbons and oxy-polycyclic aromatic hydrocarbons in ambient air in urban and rural areas in northern China. Environ. Pollut. 197, 156-164. https://doi.org/10.1016/j.envpol.2014.12.019

Li, X., Liu, Y., Li, D., Wang, G., Bai, Y., Diao, H., Shen, R., Hu, B., Xin, J., Liu, Z., Wang, Y., Guo, X., Wang, L. (2017a). Molecular composition of organic aerosol over an agricultural site in North China Plain: Contribution of biogenic sources to PM2.5. Atmos. Environ. 164, 448-457. https://doi.org/10.1016/j.atmosenv.2017.06.018

Lin, Y., Ma, Y.Q., Qiu, X.H., Li, R., Fang, Y.H., Wang, J.X., Zhu, Y.F., Hu, D. (2015). Sources, transformation, and health implications of PAHs and their nitrated, hydroxylated, and oxygenated derivatives in $\mathrm{PM}_{2.5}$ in Beijing J. Geophys. Res. 120, 7219-7228. https://doi.org/10.1 002/2015jd023628

Li, Y., Wang, W., Yang, L., Chen, X., Gao, Y., Jiang, P., Zhang, J., Yu, H. (2017b). PM2.5-bound PAHs in indoor and outdoor of hotels in urban and suburban of Jinan, China: Concentrations, sources, and health risk impacts. Aerosol Air Qual. Res. 17, 2463-2473. https://doi.org/10.4209/aaqr.2 017.08.0286

Liu, X., Li, C., Tu, H., Wu, Y., Ying, C., Huang, Q., Wu, S., Xie, Q., Yuan, Z., Lu, Y. (2016). Analysis of the effect of meteorological factors on $\mathrm{PM}_{2.5}$-associated pahs during autumn-winter in urban Nanchang. Aerosol Air Qual. Res. 16, 3222-3229. https://doi.org/10.4209/aaqr.2016.08.0351

Liu, X., Meng, J., Hou, Z., Yan, L., Wang, G., Yi, Y., Wei, B., Fu, M., Li, J., Cao, J. (2019). Molecular compositions and sources of organic aerosols from urban atmosphere in the North China Plain during the wintertime of 2017. Aerosol Air Qual. Res. 19, 2267-2280. https://doi.org/10.4209/ aaqr.2019.08.0418

Manousakas, M., Papaefthymiou, H., Diapouli, E., Migliori, A., Karydas, A.G., Bogdanovic-Radovic, I., Eleftheriadis, K. (2017). Assessment of $\mathrm{PM}_{2.5}$ sources and their corresponding level of uncertainty in a coastal urban area using EPA PMF 5.0 enhanced diagnostics. Sci. Total Environ. 574, 155-164. https://doi.org/10.1016/j.scitotenv.2016.09.047

Meng, J.J., Wang, G.H., Hou, Z.F., Liu, X.D., Wei, B.J., Wu, C., Cao, C., Wang, J.Y., Li, J.J., Cao, J.J., Zhang, E.X., Dong, J., Liu, J.Z., Ge, S.S., Xie, Y.N. (2018). Molecular distribution and stable carbon 
isotopic compositions of dicarboxylic acids and related SOA from biogenic sources in the summertime atmosphere of Mt. Tai in the North China Plain. Atmos. Chem. Phys. 18, 1506915086. https://doi.org/10.5194/acp-18-15069-2018

Meng, J., Liu, X., Hou, Z., Yi, Y., Yan, L., Li, Z., Cao, J., Li, J., Wang, G. (2020). Molecular characteristics and stable carbon isotope compositions of dicarboxylic acids and related compounds in the urban atmosphere of the North China Plain: Implications for aqueous phase formation of SOA during the haze periods. Sci. Total Environ. 705, 135256. https://doi.org/10.1 016/j.scitotenv.2019.135256

Niu, X.Y., Ho, S.S.H., Ho, K.F., Huang, Y., Sun, J., Wang, Q.Y., Zhou, Y.Q., Zhao, Z.Z., Cao, J.J. (2017). Atmospheric levels and cytotoxicity of polycyclic aromatic hydrocarbons and oxygenated-PAHs in $\mathrm{PM}_{2.5}$ in the Beijing-Tianjin-Hebei region. Environ. Pollut. 231, 1075-1084. https://doi.org/1 0.1016/j.envpol.2017.08.099

Oliveira, C., Pio, C., Alves, C., Evtyugina, M., Santos, P., Gonçalves, V., Nunes, T., Silvestre, A.J.D., Palmgren, F., Wåhlin, P., Harrad, S. (2007). Seasonal distribution of polar organic compounds in the urban atmosphere of two large cities from the North and South of Europe. Atmos. Environ. 41, 5555-5570. https://doi.org/10.1016/j.atmosenv.2007.03.001

Qiao, M., Qi, W.X., Liu, H.J., Qu, J.H. (2014). Oxygenated, nitrated, methyl and parent polycyclic aromatic hydrocarbons in rivers of Haihe River System, China: Occurrence, possible formation, and source and fate in a water-shortage area. Sci. Total Environ. 481, 178-185. https://doi.org/ 10.1016/j.scitotenv.2014.02.050

Shen, G.F., Tao, S., Wang, W., Yang, Y.F., Ding, J.N., Xue, M.A., Min, Y.J., Zhu, C., Shen, H.Z., Li, W., Wang, B., Wang, R., Wang, W.T., Wang, X.L., Russell, A.G. (2011). Emission of oxygenated polycyclic aromatic hydrocarbons from indoor solid fuel combustion. Environ. Sci. Technol. 45, 3459-3465. https://doi.org/10.1021/es104364t

Shen, G.F., Tao, S., Wei, S.Y., Zhang, Y.Y., Wang, R., Wang, B., Li, W., Shen, H.Z., Huang, Y., Chen, Y.C., Chen, H., Yang, Y.F., Wang, W., Wang, X.L., Liu, W.X., Simonich, S.L.M. (2012). Emissions of parent, nitro, and oxygenated polycyclic aromatic hydrocarbons from residential wood combustion in rural China. Environ. Sci. Technol. 46, 8123-8130. https://doi.org/10.1021/es301146v

Shen, G.F., Tao, S., Wei, S.Y., Chen, Y.C., Zhang, Y.Y., Shen, H.Z., Huang, Y., Zhu, D., Yuan, C.Y., Wang, H.C., Wang, Y.F., Pei, L.J., Liao, Y.L., Duan, Y.H., Wang, B., Wang, R., Lv, Y., Li, W., Wang, X.L., Zheng, X.Y. (2013). Field measurement of emission factors of PM, EC, OC, parent, nitro-, and oxy- polycyclic aromatic hydrocarbons for residential briquette, coal cake, and wood in rural Shanxi, China. Environ. Sci. Technol. 47, 2998-3005. https://doi.org/10.1021/es304599g

Shen, G.F., Chen, Y.C., Xue, C.Y., Lin, N., Huang, Y., Shen, H.Z., Wang, Y.L., Li, T.C., Zhang, Y.Y., Su, S., Huangfu, Y.B., Zhang, W.H., Chen, X.F., Liu, G.Q., Liu, W.X., Wang, X.L., Wong, M.H., Tao, S. (2015). Pollutant emissions from improved coal- and wood-fuelled cookstoves in rural households. Environ. Sci. Technol. 49, 6590-6598. https://doi.org/10.1021/es506343z

Shi, G., Liu, G., Tian, Y., Zhou, X., Peng, X., Feng, Y. (2014). Chemical characteristic and toxicity assessment of particle associated PAHs for the short-term anthropogenic activity event: During the Chinese New Year's Festival in 2013. Sci. Total Environ. 482-483, 8-14. https://doi.org/10. 1016/j.scitotenv.2014.02.107

Shi, M., Hu, T., Mao, Y., Cheng, C., Liu, W., Tian, Q., Chen, Z., Xing, X., Qi, S. (2020). Polycyclic aromatic hydrocarbons in atmospheric $\mathrm{PM}_{2.5}$ during winter haze in Huang-Gang, Central China: Characteristics, sources and health risk assessment. Aerosol Air Qual. Res. 21, 200337. https://doi.org/10.4209/aaqr.2020.06.0337

Tan, J., Guo, S., Ma, Y., Duan, J., Cheng, Y., He, K., Yang, F. (2011). Characteristics of particulate pahs during a typical haze episode in Guangzhou, China. Atmos. Res. 102, 91-98. https://doi.org/10.1016/j.atmosres.2011.06.012

Tian, S., Pan, Y., Liu, Z., Wen, T., Wang, Y. (2014). Size-resolved aerosol chemical analysis of extreme haze pollution events during early 2013 in urban Beijing, China. J. Hazard. Mater. 279, 452-460. https://doi.org/10.1016/j.jhazmat.2014.07.023

Tian, X., Cui, K., Sheu, H.L., Hsieh, Y.K., Yu, F. (2021). Effects of rain and snow on the air quality index, $\mathrm{PM}_{2.5}$ levels, and dry deposition flux of PCDD/Fs. Aerosol Air Qual. Res. 21, 210158. http://doi.org./10.4209/aaqr.210158

Wan, E.C.H., Yu, J.Z. (2007). Analysis of sugars and sugar polyols in atmospheric aerosols by chloride attachment in liquid chromatography/negative ion electrospray mass spectrometry. 
Environ. Sci. Technol. 41, 2459-2466. https://doi.org/10.1021/es062390g

Wang, G., Kawamura, K., Lee, S., Ho, K., Cao, J. (2006). Molecular, seasonal, and spatial distributions of organic aerosols from fourteen Chinese cities. Environ. Sci. Technol. 40, 46194625. https://doi.org/10.1021/es060291x

Wang, G., Xie, M., Hu, S., Gao, S., Tachibana, E., Kawamura, K. (2010). Dicarboxylic acids, metals and isotopic compositions of $\mathrm{C}$ and $\mathrm{N}$ in atmospheric aerosols from inland China: Implications for dust and coal burning emission and secondary aerosol formation. Atmos. Chem. Phys. 10, 6087-6096. https://doi.org/10.5194/acp-10-6087-2010

Wang, G., Cheng, S., Lang, J., Yang, X., Wang, X., Chen, G., Liu, X., Zhang, H. (2017). Characteristics of $\mathrm{PM}_{2.5}$ and assessing effects of emission-reduction measures in the heavy polluted city of Shijiazhuang, before, during, and after the ceremonial parade 2015. Aerosol Air Qual. Res. 17, 499-512. https://doi.org/10.4209/aaqr.2016.05.0181

Wang, G.H., Li, J.J., Cheng, C.L., Zhou, B.H., Xie, M.J., Hu, S.Y., Meng, J.J., Sun, T., Ren, Y.Q., Cao, J.J., Liu, S.X., Zhang, T., Zhao, Z.Z. (2012). Observation of atmospheric aerosols at Mt. Hua and Mt. Tai in central and east China during spring 2009 - Part 2: Impact of dust storm on organic aerosol composition and size distribution. Atmos. Chem. Phys. 12, 4065-4080. https://doi.org/ 10.5194/acp-12-4065-2012

Wang, J.Z., Ho, S.S.H., Huang, R.J., Gao, M.L., Liu, S.X., Zhao, S.Y., Cao, J.J., Wang, G.H., Shen, Z.X., Han, Y.M. (2016). Characterization of parent and oxygenated-polycyclic aromatic hydrocarbons (PAHs) in Xi'an, China during heating period: An investigation of spatial distribution and transformation. Chemosphere 159, 367-377. https://doi.org/10.1016/j.chemosphere.2016.0 6.033

Wang, X., Cheng, H., Xu, X., Zhuang, G., Zhao, C. (2008). A wintertime study of polycyclic aromatic hydrocarbons in $\mathrm{PM}_{2.5}$ and $\mathrm{PM}_{2.5-10}$ in Beijing: Assessment of energy structure conversion. J. Hazard. Mater. 157, 47-56. https://doi.org/10.1016/j.jhazmat.2007.12.092

Wang, Y.Q., Zhang, X.Y., Draxler, R.R. (2009). TrajStat: GIS-based software that uses various trajectory statistical analysis methods to identify potential sources from long-term air pollution measurement data. Environ. Modell. Software 24, 938-939. https://doi.org/10.1016/j.envsoft. 2009.01.004

Wei, S.L., Huang, B., Liu, M., Bi, X.H., Ren, Z.F., Sheng, G.Y., Fu, J.M. (2012). Characterization of $\mathrm{PM}_{2.5}$-bound nitrated and oxygenated PAHs in two industrial sites of South China. Atmos. Res. 109, 76-83. https://doi.org/10.1016/j.atmosres.2012.01.009

Wei, X.Y., Liu, M., Yang, J., Du, W.N., Sun, X., Huang, Y.P., Zhang, X., Khalil, S.K., Luo, D.M., Zhou, Y.D. (2019). Characterization of $\mathrm{PM}_{2.5}$-bound PAHs and carbonaceous aerosols during threemonth severe haze episode in Shanghai, China: Chemical composition, source apportionment and long-range transportation. Atmos. Environ. 203, 1-9. https://doi.org/10.1016/j.atmosenv. 2019.01.046

Yang, L., Zhou, X., Wang, Z., Zhou, Y., Cheng, S., Xu, P., Gao, X., Nie, W., Wang, X., Wang, W. (2012). Airborne fine particulate pollution in Jinan, China: Concentrations, chemical compositions and influence on visibility impairment. Atmos. Environ. 55, 506-514. https://doi.org/10.1016/j.atm osenv.2012.02.029

Yang, S., Ma, Y.L., Duan, F.K., He, K.B., Wang, L.T., Wei, Z., Zhu, L.D., Ma, T., Li, H., Ye, S.Q. (2018). Characteristics and formation of typical winter haze in Handan, one of the most polluted cities in China. Sci. Total Environ. 613, 1367-1375. https://doi.org/10.1016/j.scitotenv.2017.08.033

Yi, Y., Meng, J., Hou, Z., Wang, G., Zhou, R., Li, Z., Li, Y., Chen, M., Liu, X., Li, H., Yan, L. (2021). Contrasting compositions and sources of organic aerosol markers in summertime $\mathrm{PM}_{2.5}$ from urban and mountainous regions in the North China Plain. Sci. Total Environ. 766, 144187. https://doi.org/10.1016/j.scitotenv.2020.144187

Zhang, F., Wang, Y., Peng, J.F., Chen, L., Sun, Y.L., Duan, L., Ge, X.L., Li, Y.X., Zhao, J.Y., Liu, C., Zhang, X.C., Zhang, G., Pan, Y.P., Wang, Y.S., Zhang, A.L., Ji, Y.M., Wang, G.H., Hu, M., Molina, M.J., Zhang, R.Y. (2020). An unexpected catalyst dominates formation and radiative forcing of regional haze. Proc. Natl. Acad. Sci. U.S.A. 117, 3960-3966. https://doi.org/10.1073/pnas.1919343117

Zhang, J., Yuan, Q., Liu, L., Wang, Y., Zhang, Y., Xu, L., Pang, Y., Zhu, Y., Niu, H., Shao, L., Yang, S., Liu, H., Pan, X., Shi, Z., Hu, M., Fu, P., Li, W. (2021). Trans-regional transport of haze particles from the North China Plain to Yangtze River Delta during winter. J. Geophys. Res. 126, e2020JD033778. https://doi.org/10.1029/2020JD033778 
Zhang, N., Cao, J., Liu, S., Zhao, Z., Xu, H., Xiao, S. (2014). Chemical composition and sources of $\mathrm{PM}_{2.5}$ and TSP collected at Qinghai Lake during summertime. Atmos. Res. 138, 213-222. https://doi.org/10.1016/j.atmosres.2013.11.016

Zhang, Z., Gao, J., Engling, G., Tao, J., Chai, F., Zhang, L., Zhang, R., Sang, X., Chan, C.Y., Lin, Z., Cao, J. (2015). Characteristics and applications of size-segregated biomass burning tracers in China's Pearl River Delta region. Atmos. Environ. 102, 290-301. https://doi.org/10.1016/j.atmosenv.2 014.12.009

Zhou, S.Z., Yang, L.X., Gao, R., Wang, X.F., Gao, X.M., Nie, W., Xu, P.J., Zhang, Q.Z., Wang, W.X. (2017). A comparison study of carbonaceous aerosols in a typical North China Plain urban atmosphere: Seasonal variability, sources and implications to haze formation. Atmos. Environ. 149, 95-103. https://doi.org/10.1016/j.atmosenv.2016.11.009 